\title{
Guiding Curriculum Development: Student Perceptions for the Second Language Learning in Technology-Enhanced Learning Environments
}

\author{
Sinan Gürleyik ${ }^{1}$, Elif Akdemir ${ }^{2}$ \\ ${ }^{1}$ The Institute of Social Sciences, Bülent Ecevit University, Zonguldak, Turkey \\ ${ }^{2}$ Ereğli Education Faculty, Bülent Ecevit University, Zonguldak, Turkey \\ Correspondence: Elif Akdemir, Bülent Ecevit University, Ereğli Education Faculty, Kdz Ereğli, Zonguldak, Turkey.
}

Received: February 5, 2018

Accepted: March 10, $2018 \quad$ Online Published: March 18, 2018

doi:10.11114/jets.v6i4.2994

URL: https://doi.org/10.11114/jets.v6i4.2994

\begin{abstract}
Developing curriculum to enhance student learning is the primer purpose of all curricular activities. Availability of recent tools supporting to teach various skills including reading, listening, speaking and writing has opened a new avenue for curricular activities in technology-enhanced learning environments. Understanding the perceptions of students utilizing technology-enhanced learning environments to learn second language skills is important to develop the curriculum. This study is organized to investigate the perceptions of students towards second language learning in technology-enhanced learning environments in which students can develop reading, listening, speaking and writing skills for the second language learning. The survey was used to collect data from 875 undergraduate students involved in technology-enhanced second language learning environments in a university. Contrary to general expectations, results of the study indicated that technology-enhanced learning environments do not positively influence the perceptions of undergraduate students for the second language learning. Further research should concentrate on investigating the reasons behind these findings using qualitative studies.
\end{abstract}

Keywords: curriculum development, student perception, language learning, technology

\section{Introduction}

Developing curriculum to enhance student learning is the primer purpose of all curricular activities. Availability of recent tools supporting to teach various skills including reading, listening, speaking and writing has opened a new avenue for curricular activities in technology-enhanced learning environments. Understanding the effects of using technology to enhance learning in foreign language classes is important to develop the curriculum. Studies have been conducted to investigate the effects of the technology on second language learning (Afshari et al., 2013; Başöz and Çubukçu, 2014; Chang et al., 2015; Golshan and Tafazoli, 2014; Köse et al., 2016; Lai, 2015; Lai et al., 2016; Martins, 2015; Öz, 2015; Pinto-Llorente et al., 2017; Rahimi and Yadollahi, 2011; Sarfraz et al., 2015; Sung and Yeh, 2012; Swart, 2017; Yang and Chen, 2007; Zamari et al., 2012).

Using technology in foreign language learning programs appears to influence the perceptions of students. There are studies investigating the perceptions of students and/or teachers towards using technology for the second language teaching (Sarfraz et al., 2015; Sung and Yeh, 2012; Zamari et al., 2012). Sung and Yeh (2012) investigated students' perceptions towards the foreign language learning with the data collected from Taiwanese freshman utilizing qualitative approach. The Live ABC e-Paper of the library web-site consisting of five categories such as Daily Life, Living Environment, Transportation, Entertainment and Festivals, was used as the online learning material. Findings showed that majority of the participants had positive attitudes toward the Live ABC e-Paper. Moreover, participants found the Live ABC e-Paper helpful for learning English. In another study, Zamari et al. (2012) carried out a study to explore the students' perceptions towards using online learning materials and the challenges they face using online learning materials with 97 students, who attended Consolidating Language Skills classes in a university. The results showed that most of the students were motivated to use web-based online learning materials even when this activity was no longer required for the purpose of assessment. As the reason for using online learning materials, half of the students stated that they went online because of the course requirement, and the other half for the self-fulfillment. Moreover, most of the students reported that internet connection was the main challenge they face during the online learning process. Similarly, Sarfraz et al. (2015) conducted a study to assess the perceptions of students and teachers using the Communicative Teaching Methodology in Computer 
Assisted Language Learning with the data collected from 50 Computer Sciences Degree program students. The results of the study showed that the communicative activities involving Computer Assisted Language Learning reflect positive attitudes of the students. Using CALL gives students more freedom over their learning. However students' perceptions in terms of the usefulness of the activities varied. Also, Chang et al. (2015) examined 22 studies on developing instruments that evaluate teachers' and students' perceptions in technology-enhanced learning environments. The study aimed to offer a novel framework which conceptualize the technology-supported learning environments based on the review of the instruments used in those studies. The Web of Science to search the articles were used. Six important dimensions of Technology Supported Learning Environments consisting of technical, content, cognitive, metacognitive, social, and affective were identified as a result of the analysis of 22 empirical studies.

Besides investigating the effects of the technology for second language teaching, studies have also examined the attitudes of students towards using technology for second language teaching (Afshari et al., 2013; Öz, 2015). Afshari et al. (2013) conducted a study to investigate the attitudes of students towards using the computer-assisted language learning (CALL) with 100 Languages and Linguistics undergraduate students. The results of the structural equation modeling revealed that students had moderate attitude toward CALL. In another study, the relationship between language learners' attitudes towards foreign language learning and computer-assisted language learning (CALL) was investigated by Öz (2015) with the data collected from 128 undergraduate freshmen students. The Computer Assisted Language Learning Scale was used for the data collection. The findings of the study indicated that participants had positive attitudes towards learning foreign language and the integration of computer-assisted language learning. The findings also indicated a strong positive correlation between participants' attitudes towards learning foreign language and computer-assisted language learning. In another study, Rahimi and Yadollahi (2011) carried out a study to investigate the relationship between attitudes of female students towards computer-assisted language learning (CALL) and attitudes towards foreign language learning (FLL). According to the findings, attitudes of female students towards computer-assisted language learning and attitudes towards foreign language learning were positive. Moreover, a positive correlation was found between CALL and FLL.

Combining the investigation of the students' perceptions towards technical tools and attitudes towards technical tools for language learning, Pinto-Llorente et al. (2017) conducted a study to explore students' perceptions and attitudes towards asynchronous tools. The data from the participants were collected through the survey. The results of the study indicated that students' perceptions and attitudes towards the technological tools were rather positive. Most students stated that blended learning model designed via Moodle was effective in improving students' grammar competence.

In contrast to the positive results of participants towards the use of technology in foreign language learning environments, part of some research studies revealed complaints about the use of the technology for the second language learning. Köse et al. (2016) conducted a study to investigate the effects of the online website used to contribute the vocabulary development of students with the data collected from 43 preparatory students at a university. According to the results of the study, most students found the online tool effective particularly at the beginning stages of the vocabulary learning. Students seemed really motivated while self-studying on the website during class hours based on the classroom observations. Also majority of the students found the website useful in terms of learning vocabulary. However, some participants complained about the lack of examples including new words. In another study, Yang and Chen (2007) carried out a descriptive study to explore participants' opinions about the integration of internet tools in language learning activities. The Advanced Joint English Teaching Program (AJET) program aiming to provide students an authentic language learning context to communicate through online discussions, e-mail, videoconferences and others was used in the study. The sample of the study consisted of 44 senior high school students and their teacher in Taiwan. Results indicated that majority of the students enjoyed the English learning via Internet. Most learners believed that the Internet promoted and enhanced language learning but the technology was not benefited enough because of the limited time, technical failures, limited administrative support, and various resources offered over the Internet. In another study investigating the English as Foreign Language (EFL) teachers' attitudes towards Technology-Enhanced Language Learning (TELL) with the data collected from 32 EFL teachers who were administered a questionnaire, Golshan and Tafazoli (2014) found that integrating TELL programs and tools into language classrooms is beneficial to create a positive attitude in teachers on the use of technology in classes. Most teachers stated that the TELL tools as effective factor in language teaching. Also, the semi-structured interview revealed that any technology-based tools help students learn and teachers to teach English. However, some participants complained about not being allowed to use some TELL tools like mobile phones. Finally, Başöz and Çubukçu (2014) investigated the attitudes of pre-service EFL teachers towards Computer Assisted Language Learning (CALL) with the data collected from 112 pre-service teachers studying at the English Language Teaching Department and found that CALL developed mostly their listening skills and vocabulary. Most of them also stated that CALL provided a more relaxed and stress-free atmosphere. However, participants declared that CALL did not develop their writing and oral skills.

Swart (2017) also found that the students' development of critical thinking potentially can be improved by the integration of the technology-enhanced learning environments into the classes. It is also stated that the use of authentic 
materials in English language contributes to students' motivation, their reading and finding out new vocabulary, and also to their development of critical cultural awareness (Martins, 2015). Besides technology, teachers play important role in language learning. Lai (2015) found that teachers' support influences learners' self-directed technology use through straightened perceived usefulness, enhanced facilitating conditions and computer self-efficacy.

Although there are many factors playing roles on the effects of the technology in foreign language learning, little is known about the use of language curriculum design and language learning processes that underlies the EFL (Rodrigues, 2015). Understanding the perceptions of students utilizing technology-enhanced learning environments to learn second language skills is important to develop curricular activities. This study is organized to investigate the student perceptions for the second language learning on technology-enhanced learning environments in which students can develop reading, listening, speaking and writing skills for the second language learning. Following research questions were developed to investigate the issue;

1. Does the perception of the students using the technology-enhanced learning environment for the second language learning change by the gender? (H01, H02, H03, H04, H05)

2. Does the perception of the students using the technology-enhanced learning environment for the second language learning change by the department? (H06, H07, H08, H09, H010)

3. Does the perception of the students using the technology-enhanced learning environment for the second language learning change by the level of English? (H011, H012, H013, H014, H015)

4. Does the perception of the students using the technology-enhanced learning environment for the second language learning change by the device students use to access the technology-enhanced learning environment? (H016, H017, H018, H019, H020)

\section{Method}

The cross-sectional survey design was used in the study. A cross-sectional study is preferred to examine current the attitudes, beliefs, opinions, or practices of participants (Creswell, 2002). Student perceptions for the second language learning in technology-enhanced learning environments is examined in the study. Figure 1. shows the study design and tested hypotheses.

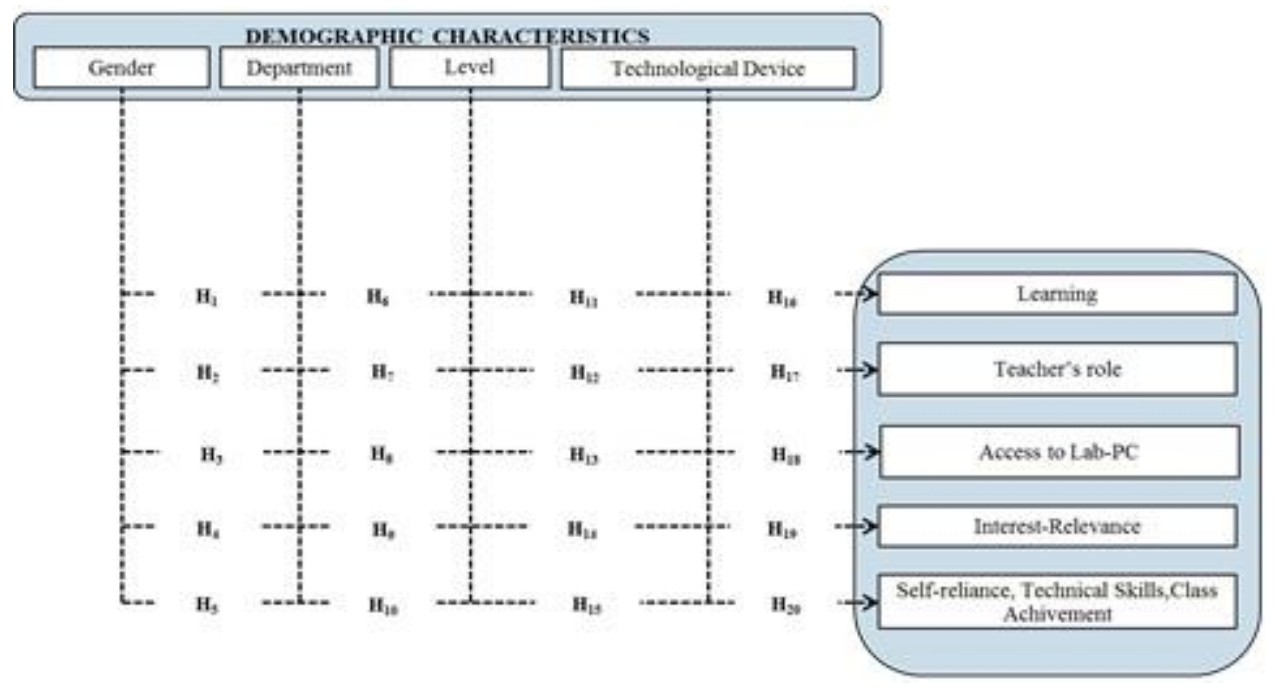

Figure 1 . The study design and tested hypotheses

\subsection{Instrument}

The questionnaire was used for the data collection. The questionnaire has two parts. The first part of the questionnaire has four questions inquiring information about the gender, department, the level of English and the device students use to access the technology-enhanced learning environment. The second part of the questionnaire was adopted from the questionnaire on student perceptions about technology use for foreign language instruction developed by Stepp-Greany (2002). The second part of the questionnaire has 44 questions regarding the perceptions of students for the teacher's role and facilitation, for the access to lab and computers, for the effect on learning, for the interest and relevance, and for the effect on confidence as a learner, technical skills, and class assessments. The overall internal consistency coefficient score of the instrument is 0.944 . The internal consistency coefficient score of the instrument for the sub-factors is presented in the Table 1. 
Table 1. The internal consistency coefficient scores

\begin{tabular}{lcc}
\hline & $\begin{array}{c}\text { Number of } \\
\text { Questions }\end{array}$ & $\begin{array}{c}\text { Internal Consistency } \\
\text { Coefficient }(\alpha)\end{array}$ \\
\hline Effect on learning & 14 & 0,883 \\
Teacher's role and facilitation & 7 & 0,777 \\
Access to lab and computers & 4 & 0,590 \\
Interest and relevance & 10 & 0,867 \\
Effect on confidence as a learner, technical & 9 & 0,867 \\
skills, and class assessments & 44 & 0,944 \\
Overall & 4 & \\
\hline
\end{tabular}

\subsection{Context}

The study conducted in Karabük University. The university was established in 2007 as a public university. Attending technology-enhanced English language preparation program is compulsory for the Engineering department and foreign languages department students. Attending the program for other department students is elective. Students improve their reading, writing, listening and speaking skills in the technology-enhanced English language preparation program of the University.

\subsection{Instruction}

The commercially available online skills program was used in the English language preparation program of the University. This online skills program provides students a mean for communicating with instructors. Instructors can follow the student progress inside and outside the class. The curriculum of the English language preparation program is designed in a way that students have to attend the compulsory lab sessions requiring the completion of the step-by-step activities designed to support reading, listening, writing and speaking skills. Besides in class activities, students can access the learning materials outside the class using the web technologies and can work independently. Also instructors can assign students extra activities to be completed outside the class. Instructors can also monitor individual and group progress of their students on the online skills program.

\subsection{Participant Selection}

The study population consisted of 1100 undergraduate prep-class students in Karabük University. Data for the study were obtained on a volunteer basis from undergraduate students of Karabük University who were attending the English preparation classes. Holistic sampling approach was used in the study to select the participants. 875 undergraduate prep-class students using technology-enhanced learning environments to learn second language participated in the study. The data were collected in the 2015-2016 academic year. The demographic information of the participants is presented at the Table 2.

Table 2. Participants' demographic information

\begin{tabular}{|c|c|c|c|c|c|c|c|}
\hline Sex & $\mathrm{f}$ & $\%$ & \multicolumn{3}{|c|}{ Department } & $\mathrm{f}$ & $\%$ \\
\hline Female & 243 & 27,8 & \multicolumn{3}{|c|}{ Engineering Departments (compulsory) } & 708 & 80,9 \\
\hline Male & 632 & 72,2 & \multicolumn{3}{|c|}{ Foreign Language Department (compulsory) } & 69 & 7,9 \\
\hline & & & \multicolumn{3}{|c|}{ Other Departments (elective) } & 98 & 11,2 \\
\hline Total & 875 & 100 & Total & & & 875 & 100 \\
\hline \multicolumn{3}{|c|}{ Level of English } & $\mathrm{f}$ & $\%$ & $\begin{array}{l}\text { Tools to access enhanced learning } \\
\text { environment }\end{array}$ & $\mathrm{f}$ & $\%$ \\
\hline \multicolumn{3}{|l|}{ A1 } & 7 & 0,8 & Desktop PCs & 109 & 12,5 \\
\hline \multicolumn{3}{|l|}{ A2 } & 302 & 34,5 & Laptop PCs & 417 & 47,7 \\
\hline \multicolumn{3}{|l|}{ B1 } & 525 & 60,0 & Tablets & 106 & 12,1 \\
\hline \multicolumn{3}{|l|}{$\mathrm{B}+$} & 41 & 4,7 & Smart Phones & 243 & 27,8 \\
\hline \multicolumn{3}{|l|}{ Total } & 875 & 100 & Total & 875 & 100 \\
\hline
\end{tabular}

\subsection{Analysis}

The data obtained from the study were analyzed using SPSS 20 for Windows software. The descriptive tests, Mann-Whitney U Test and Kruskal-Wallis H test were used to evaluate the hypotheses. Non-parametric tests were used for the data analysis because the distribution of the data were not normal. All statistical tests were conducted with a significant level of 0.05 . 


\section{Results}

The first research question investigated whether the perception of the students using the technology-enhanced learning environment for the second language learning change by the gender $\left(\mathrm{H}_{01}, \mathrm{H}_{02}, \mathrm{H}_{03}, \mathrm{H}_{04}, \mathrm{H}_{05}\right)$.

Table 3. Participants' perception by the gender

\begin{tabular}{lllllll}
\hline Factors & Gender & $\mathrm{N}$ & $\begin{array}{l}\text { Mean } \\
\text { rank }\end{array}$ & $\begin{array}{l}\text { Sum of } \\
\text { rank }\end{array}$ & $\mathrm{U}$ & $\mathrm{p}$ \\
\hline \multirow{2}{*}{ 1-Effect on learning } & Male & 632 & 430,59 & 272134,5 & 72106,5 & 0,162 \\
& Female & 243 & 457,27 & 111115,5 & & \\
2-Teacher's role and facilitation & Male & 632 & 429,46 & 271421,5 & 71393,5 & 0,107 \\
3-Access to lab and computers & Female & 243 & 460,20 & 111828,5 & & \\
& Male & 632 & 428,21 & 270628,5 & 70600,5 & 0,064 \\
& Female & 243 & 463,46 & 112621,5 & & \\
4-Interest and relevance & Male & 632 & 439,09 & 277502,0 & 76102,0 & 0,838 \\
& Female & 243 & 435,18 & 105748,0 & & \\
5-Effect on confidence & Male & 632 & 413,94 & 261632,0 & 61604,0 & $0,000^{*}$ \\
& Female & 243 & 500,49 & 121618,0 & & \\
\end{tabular}

The perception of the students was investigated for five factors including the effect on learning, teacher's role and facilitation, access to lab and computers, interest and relevance, and effect on confidence. The result of the Mann-Whitney $U$ test comparing the perception of the students for the gender revealed that the perception of the students using the technology-enhanced learning environment for the second language learning do not change by the gender except for the effect on confidence factor. The confidence level of female was higher than the confidence level of males (U=61604,0, p < 0,05) (Table 3).

The second research question was designed to investigate whether the perception of the students using the technology-enhanced learning environment for the second language learning change by the department $\left(\mathrm{H}_{06}, \mathrm{H}_{07}, \mathrm{H}_{08}\right.$, $\mathrm{H}_{09}, \mathrm{H}_{010}$ ).

Table 4. Participants' perception by the department

\begin{tabular}{|c|c|c|c|c|c|}
\hline Factors & Departments & $\mathrm{N}$ & Mean rank & Chi-Square & $\mathrm{P}$ \\
\hline \multirow{3}{*}{ 1-Effect on learning } & Engineering Departments (compulsory) & 708 & 429,17 & \multirow{3}{*}{4,531} & \multirow{3}{*}{0,104} \\
\hline & Foreign Language Department (compulsory) & 69 & 476,24 & & \\
\hline & Other Departments (elective) & 98 & 474,85 & & \\
\hline \multirow{3}{*}{ 2-Teacher's role and facilitation } & Engineering Departments (compulsory) & 708 & 427,15 & \multirow{3}{*}{7,137} & \multirow{3}{*}{$0,028 *$} \\
\hline & Foreign Language Department (compulsory) & 69 & 471,45 & & \\
\hline & Other Departments (elective) & 98 & 492,81 & & \\
\hline \multirow{3}{*}{ 3-Access to lab and computers } & Engineering Departments (compulsory) & 708 & 430,00 & \multirow{3}{*}{3,749} & \multirow{3}{*}{0,153} \\
\hline & Foreign Language Department (compulsory) & 69 & 471,75 & & \\
\hline & Other Departments (elective) & 98 & 472,04 & & \\
\hline \multirow{3}{*}{ 4-Interest and relevance } & Engineering Departments (compulsory) & 708 & 432,40 & \multirow{3}{*}{1,918} & \multirow{3}{*}{0,383} \\
\hline & Foreign Language Department (compulsory) & 69 & 454,59 & & \\
\hline & Other Departments (elective) & 98 & 466,77 & & \\
\hline \multirow{3}{*}{ 5-Effect on confidence } & Engineering Departments (compulsory) & 708 & 428,30 & \multirow{3}{*}{7,153} & \multirow{3}{*}{$0,028^{*}$} \\
\hline & Foreign Language Department (compulsory) & 69 & 509,33 & & \\
\hline & Other Departments (elective) & 98 & 457,83 & & \\
\hline
\end{tabular}

The perception of the students was investigated for five factors including the effect on learning, teacher's role and facilitation, access to lab and computers, interest and relevance, and effect on confidence. The result of the Kruskal-Wallis $\mathrm{H}$ test comparing the perception of the students for the department revealed that perception of the students for the teacher's role and facilitation change by the department $\left(X^{2}=7,137 ; p<0,05\right)$ (Table 4). Students who joined the second language learning program using the technology-enhanced learning environment voluntarily (Other Departments-elective) have more positive perception than other students in the program. Moreover the result of the Kruskal-Wallis $\mathrm{H}$ test comparing the perception of the students for the department revealed that perception of the students for the effect on confidence change by the department $\left(X^{2}=7,153 ; p<0,05\right)$ (Table 3). Students in foreign language department joining the second language learning program using the technology-enhanced learning environment mandatorily have more positive perception than students of other departments.

The third research question examined whether the perception of the students using the technology-enhanced learning environment for the second language learning change by the level of English $\left(\mathrm{H}_{011}, \mathrm{H}_{012}, \mathrm{H}_{013}, \mathrm{H}_{014}, \mathrm{H}_{015}\right)$. 
Table 5. Participants' perception by the level of English

\begin{tabular}{|c|c|c|c|c|c|}
\hline Factors & English Level & $\mathrm{N}$ & Mean rank & Chi-Square & $\mathrm{p}$ \\
\hline \multirow{4}{*}{ 1-Effect on learning } & A1 & 7 & 677,21 & \multirow{4}{*}{12,505} & \multirow{4}{*}{$0,006^{*}$} \\
\hline & $\mathrm{A} 2$ & 302 & 422,68 & & \\
\hline & B1 & 525 & 436,66 & & \\
\hline & $\mathrm{B}+$ & 41 & 527,12 & & \\
\hline \multirow{4}{*}{ 2-Teacher's role and facilitation } & A1 & 7 & 575,86 & \multirow{4}{*}{6,793} & \multirow{4}{*}{0,079} \\
\hline & $\mathrm{A} 2$ & 302 & 417,45 & & \\
\hline & $\mathrm{B} 1$ & 525 & 443,12 & & \\
\hline & $\mathrm{B}+$ & 41 & 500,20 & & \\
\hline \multirow{4}{*}{ 3-Access to lab and computers } & A1 & 7 & 617,64 & \multirow{4}{*}{15,885} & \multirow{4}{*}{$0,001 *$} \\
\hline & $\mathrm{A} 2$ & 302 & 410,17 & & \\
\hline & $\mathrm{B} 1$ & 525 & 442,69 & & \\
\hline & $\mathrm{B}+$ & 41 & 552,24 & & \\
\hline \multirow{4}{*}{ 4-Interest and relevance } & A1 & 7 & 665,21 & \multirow{4}{*}{8,237} & \multirow{4}{*}{$0,041^{*}$} \\
\hline & $\mathrm{A} 2$ & 302 & 435,28 & & \\
\hline & B1 & 525 & 431,93 & & \\
\hline & $\mathrm{B}+$ & 41 & 496,90 & & \\
\hline \multirow{4}{*}{ 5-Effect on confidence } & $\mathrm{A} 1$ & 7 & 674,00 & \multirow{4}{*}{12,607} & \multirow{4}{*}{$0,006^{*}$} \\
\hline & $\mathrm{A} 2$ & 302 & 411,73 & & \\
\hline & B1 & 525 & 444,77 & & \\
\hline & $\mathrm{B}+$ & 41 & 504,56 & & \\
\hline
\end{tabular}

\section{$* p<0,05$}

The perception of the students was investigated for five factors including the effect on learning, teacher's role and facilitation, access to lab and computers, interest and relevance, and effect on confidence. The result of the Kruskal-Wallis $\mathrm{H}$ test comparing the perception of the students for the level of English revealed that the perception of the students using the technology-enhanced learning environment for the second language learning change by the level of English except for the teacher's role and facilitation factor (Table 5). Students whose level of English is A1 have more positive perception than others.

The last research question investigated whether the perception of the students using the technology-enhanced learning environment for the second language learning change by the device students use to access the technology-enhanced learning environment $\left(\mathrm{H}_{016}, \mathrm{H}_{017}, \mathrm{H}_{018}, \mathrm{H}_{019}, \mathrm{H}_{020}\right)$.

Table 6. Participants' perception by the device students use to access the technology-enhanced learning environment

\begin{tabular}{|c|c|c|c|c|c|}
\hline Factors & Tools to access enhanced learning environment & $\mathrm{N}$ & Mean rank & Chi-Square & $\mathrm{P}$ \\
\hline \multirow{4}{*}{ 1-Effect on learning } & Desktop PCs & 109 & 442,55 & \multirow{4}{*}{0,315} & \multirow{4}{*}{0,957} \\
\hline & Laptop PCs & 417 & 441,71 & & \\
\hline & Tablets & 106 & 433,04 & & \\
\hline & Smart Phones & 243 & 431,76 & & \\
\hline \multirow{4}{*}{ 2-Teacher's role and facilitation } & Desktop PCs & 109 & 448,00 & \multirow{4}{*}{0,514} & \multirow{4}{*}{0,916} \\
\hline & Laptop PCs & 417 & 436,33 & & \\
\hline & Tablets & 106 & 425,34 & & \\
\hline & Smart Phones & 243 & 441,91 & & \\
\hline \multirow{4}{*}{ 3-Access to lab and computers } & Desktop PCs & 109 & 465,12 & \multirow{4}{*}{2,833} & \multirow{4}{*}{0,418} \\
\hline & Laptop PCs & 417 & 436,20 & & \\
\hline & Tablets & 106 & 408,19 & & \\
\hline & Smart Phones & 243 & 441,92 & & \\
\hline \multirow{4}{*}{ 4-Interest and relevance } & Desktop PCs & 109 & 461,67 & \multirow{4}{*}{1,446} & \multirow{4}{*}{0,695} \\
\hline & Laptop PCs & 417 & 433,93 & & \\
\hline & Tablets & 106 & 423,46 & & \\
\hline & Smart Phones & 243 & 440,71 & & \\
\hline \multirow{4}{*}{ 5-Effect on confidence } & Desktop PCs & 109 & 442,64 & \multirow{4}{*}{1,923} & \multirow{4}{*}{0,586} \\
\hline & Laptop PCs & 417 & 447,36 & & \\
\hline & Tablets & 106 & 446,85 & & \\
\hline & Smart Phones & 243 & 420,48 & & \\
\hline
\end{tabular}

The perception of the students was investigated for five factors including the effect on learning, teacher's role and facilitation, access to lab and computers, interest and relevance, and effect on confidence. The result of the Kruskal-Wallis $\mathrm{H}$ test comparing the perception of the students for the device students use to access the 
technology-enhanced learning environment revealed that the perception of the students using the technology-enhanced learning environment for the second language learning does change by the device students use to access the technology-enhanced learning environment (Table 6).

\section{Discussion and Conclusion}

New dimensions have been added to curriculum development with the inclusion of technology in teaching and learning activities. Guiding curriculum developers about the perception of students using the technology-enhanced learning environment is important to make accurate decisions for the curriculum development. This study is primarily designed to investigate the students' perceptions for the second language learning on technology-enhanced learning environments in which students can develop reading, listening, speaking and writing skills for the second language learning. The results of the study have contributed to make several judgements for the perception of the students using technology-enhanced learning environment for the English language learning.

Overall gender does not play a significant role on the perception of the students towards technology-enhanced learning environment for the English language learning. However, the confidence level of females was higher than the confidence level of males. Bahar (2006) found that females graduate with higher GPA than males in undergraduate programs. Therefore this finding rises a question to investigate whether there is a relation between the confidence level and GPA.

Another important finding of the study indicated that students who attended the technology-enhanced learning environment voluntarily have more positive perception about the teacher's role and facilitation. Similarly voluntary attending students' perception is higher than those students attending the program because of the program requirements. Zamari et al. (2012) found that even it was no longer required part of the course, most students were motivated to use the web-based online learning materials. It seems that not only the technology-enhanced learning environment but also the willingness of students to attend the program improves the perception of the students.

Moreover it is found that students whose English language level is higher have more positive perception than other students with lower English language level in technology-enhanced learning environment. Is the increase on the perception due to the technology-enhanced learning environment? Or is it the attribute of successful students for any learning environment? These are open questions to investigate because Sung and Yeh (2012) found that majority of the participants had positive attitudes toward the learning material using the web technologies. However it is also found in this study that the perception of the students using the technology-enhanced learning environment for the second language learning does change by the device students use to access the environment. This can be explained by the learner-interface interaction proclaimed by Hillman, Willis, and Gunawardena (1994).

The most important finding of this study is that in contrast to the general expectations, results of the study indicated that technology-enhanced learning environments do not positively influence the perceptions of undergraduate students for the second language learning. The overall perception level of students was low to learn English in technology-enhanced learning environments.

In conclusion, curriculum development is a planned activity which shapes the content into a form of plan for conducting effective teaching and learning. Obtaining information about the content, context, and users is important to make effective development decisions. Learning environments and means to access the environments are changing. Technology-enhanced learning environments provide numerous means to develop skills for the second language learning. Although they are not limited to, these skills include reading, listening, speaking and writing skills. Information collected in this study about the perception of students using the technology-enhanced learning environment will potentially guide the future curriculum development practices. Especially central design in curriculum emphasizes on the process which uses the selection of teaching activities, techniques and methods as a starting point (Richards, 2013). Findings of this study points out that while selecting teaching activities, techniques and methods in curriculum development, it should be kept in mind that the overall perception level of students are low to learn English in technology-enhanced learning environments. Therefore conventional means to deliver the instruction should be preferred during the development of the teaching activities, techniques and methods. Future research should concentrate on investigating the reasons while the perception level of students are low to learn English in technology-enhanced learning environments.

\section{References}

Afshari, M., Ghavifekr, S., Siraj, S., \& Jing, D. (2013). Students' attitudes towards computer-assisted language learning. Procedia-Social and Behavioral Sciences, 103, 852-859. https://doi.org/10.1016/j.sbspro.2013.10.407

Bahar, H. H. (2006). An Evaluation of KPSS Scores According to Grade Point Avarege and Gender. Education and Science, 31(140), 68-74.

Başöz, T., \& Çubukçu, F. (2014). Pre-service EFL teacher's attitudes towards Computer Assisted Language Learning (CALL). Procedia-Social and Behavioral Sciences, 116, 531-535. https://doi.org/10.1016/j.sbspro.2014.01.253 
Chang, H. Y., Wang, C. Y., Lee, M. H., Wu, H. K., Liang, J. C., Lee, S. W. Y., ... Wu, Y. T. (2015). A review of features of technology-supported learning environments based on participants' perceptions. Computers in Human Behavior, 53, 223-237. https://doi.org/10.1016/j.chb.2015.06.042

Creswell, J. W. (2002). Educational research: Planning, conducting, and evaluating quantitative (pp. 146-166). Upper Saddle River, NJ: Prentice Hall.

Daniel, C. A., Hillman, D. J. W., \& Charlotte, N. G. (2009). Learner-interface interaction in distance education: An extension of contemporary models and strategies for practitioners, American Journal of Distance Education, 8(2), 30-42. https://doi.org/10.1080/08923649409526853

de Lurdes Martins, M. (2015). How to effectively integrate technology in the foreign language classroom for learning and collaboration. Procedia-Social and Behavioral Sciences, 174, 77-84. https://doi.org/10.1016/j.sbspro.2015.01.629

Golshan, N., \& Tafazoli, D. (2014). Technology-enhanced language learning tools in Iranian EFL context: Frequencies, attitudes and challenges. Procedia-Social and Behavioral Sciences, 136, 114-118. https://doi.org/10.1016/j.sbspro.2014.05.299

Köse, T., \& Mede, E. (2016). Perceptions of EFL Learners about Using an Online Tool for Vocabulary Learning in EFL Classrooms: A Pilot Project in Turkey. Procedia-Social and Behavioral Sciences, 232, 362-372. https://doi.org/10.1016/j.sbspro.2016.10.051

Lai, C. (2015). Modeling teachers' influence on learners' self-directed use of technology for language learning outside the classroom. Computers \& Education, 82, 74-83. https://doi.org/10.1016/j.compedu.2014.11.005

Lai, C., Wang, Q., Li, X., \& Hu, X. (2016). The influence of individual espoused cultural values on self-directed use of technology for language learning beyond the classroom. Computers in Human Behavior, 62, 676-688. https://doi.org/10.1016/j.chb.2016.04.039

Öz, H. (2015). Investigating the relationship between foreign language learning and call attitudes among EFL freshman students. Procedia-Social and Behavioral Sciences, 176, 1041-1049. https://doi.org/10.1016/j.sbspro.2015.01.576

Pinto-Llorente, A. M., Sánchez-Gómez, M. C., García-Peñalvo, F. J., \& Casillas-Martín, S. (2017). Students’ perceptions and attitudes towards asynchronous technological tools in blended-learning training to improve grammatical competence in English as a second language. Computers in Human Behavior, 72, 632-643. https://doi.org/10.1016/j.chb.2016.05.071

Rahimi, M., \& Yadollahi, S. (2011). Foreign language learning attitude as a predictor of attitudes towards computer-assisted language learning. Procedia Computer Science, 3, 167-174. https://doi.org/10.1016/j.procs.2010.12.029

Richards, J. C. (2013). Curriculum approaches in language teaching: Forward, central, and backward design. Relc Journal, 44(1), 5-33. https://doi.org/10.1177/0033688212473293

Rodrigues, E. N. (2015). Curriculum design and language learning: An analysis of English textbooks in Brazil. Andrews University.

Sarfraz, S., Mansoor, Z., \& Tariq, R. (2015). Teachers' and Students' Perceptions of the Communicative Language Teaching Methodology in the CALL Environment: A Case Study. Procedia-Social and Behavioral Sciences, 199, 730-736. https://doi.org/10.1016/j.sbspro.2015.07.604

Stepp-Greany, J. (2002). Student perceptions on language learning in a technological environment: Implications for the new millennium. Language Learning \& Technology, 6(1), 165-180.

Sung, D., \& Yeh, C. Y. (2012). Perceptions of using online technology in language education: An interview study with Taiwanese university students. Procedia-Social and Behavioral Sciences, 51, 405-410. https://doi.org/10.1016/j.sbspro.2012.08.180

Swart, R. (2017). Critical thinking instruction and technology-enhanced learning from the student perspective: A mixed methods research study. Nurse Education in Practice, 23, 30-39. https://doi.org/10.1016/j.nepr.2017.02.003

Yang, S. C., \& Chen, Y. J. (2007). Technology-enhanced language learning: A case study. Computers in Human Behavior, 23(1), 860-879. https://doi.org/10.1016/j.chb.2006.02.015

Zamari, Z. M., Adnan, A. H. M., Idris, S. L., \& Yusof, J. (2012). Students' perception of using online language learning materials. Procedia-Social And Behavioral Sciences, 67, 611-620. https://doi.org/10.1016/j.sbspro.2012.11.367

\section{Copyrights}

Copyright for this article is retained by the author(s), with first publication rights granted to the journal.

This is an open-access article distributed under the terms and conditions of the Creative Commons Attribution license which permits unrestricted use, distribution, and reproduction in any medium, provided the original work is properly cited. 